\title{
Demographic factors and quality of life of patients after myocardial infarction
}

\section{Czynniki demograficzne a jakość życia pacjentów po zawale mięśnia sercowego}

\author{
Małgorzata Kołpa ${ }^{1}$, Aneta Grochowska1, Anna Damasiewicz-Borowska² \\ ${ }^{1}$ Department of Nursing, Faculty of Health Sciences, University of Applied Sciences, Tarnow, Poland \\ Head of the Department: Barbara Kubik PhD \\ ${ }^{2}$ Cardiology Department, Voivodeship Hospital St. Luka, Tarnów, Poland \\ Head of the Department: Jarosław Blicharz MD
}

Key words: myocardial infarction, quality of life, biopsychosocial functioning, WHOQOL-BREF.

Słowa kluczowe: zawał serca, jakość życia, funkcjonowanie biopsychospołeczne, WHOQOL-BREF.

\begin{abstract}
Introduction: Myocardial infarction is a serious problem for many patients, but despite the associated risks, the patient can lead a normal life and the infarction incident itself usually does not limit the patient's future possibilities.

Aim of the research: To evaluate the quality of life of patients after myocardial infarction.

Material and methods: The study was carried out using the diagnostic survey method with the use of a self-designed questionnaire and the WHOQOL-BREF standardized questionnaire. 100 patients of St. Luke Regional Hospital in Tarnów, Cardiology Department and Cardiology Outpatient Clinic were examined in the period from September to December 2017. The average age was $66.76 \pm 10.04$ years. The analysis assumed the significance level of 0.05 .

Results: The average quality of life assessment made by the respondents was $3.52 \pm 0.86$ points, which means that they assessed their quality of life between good and average (neither good nor bad). The higher age of patients lowered the quality of life in each of the functional areas $(p \leq 0.001)$. Men after myocardial infarction scored higher in terms of overall quality of life and health as well as in psychological and environmental areas, compared to women $(p<0.05)$. Married patients presented a higher overall quality of life and their own health and in physical, psychological and environmental areas $(p<0.01)$. A higher level of education was associated with a better quality of life and health as well as quality in all areas of functioning $(p<0.05)$. Professionally active people had a higher quality of life and health as well as quality of life in each of the areas, compared to retired people or pensioners $(p<0.001)$.

Conclusions: Sociodemographic factors such as age, sex, marital status, education and professional status had an impact on the quality of life of patients after myocardial infarction.
\end{abstract}

\section{Streszczenie}

Wprowadzenie: Zawał mięśnia sercowego stanowi poważny problem wielu pacjentów, jednak pomimo zagrożeń z nim związanych chory może prowadzić normalne życie, a sam incydent zawałowy zwykle nie ogranicza możliwości pacjenta w przyszłości.

Cel pracy: Ocena jakości życia pacjentów po zawale mięśnia sercowego.

Materiał i metody: Badania przeprowadzono metodą sondażu diagnostycznego z wykorzystaniem kwestionariusza ankiety własnej konstrukcji i kwestionariusza standaryzowanego WHOQOL-BREF. Zbadano 100 pacjentów Szpitala Wojewódzkiego im. św. Łukasza w Tarnowie, Oddziału Kardiologii oraz poradni kardiologicznej od września do grudnia 2017 r. $\mathrm{W}$ analizie przyę̨to poziom istotności 0,05.

Wyniki: Średnia ocena jakości życia dokonana przez ankietowanych wyniosła 3,52 $\pm 0,86$ pkt. Wyższy wiek pacjentów obniżał jakość życia w każdej z dziedzin funkcjonowania ( $p \leq 0,001)$. Mężczyźni po zawale serca uzyskiwali wyższe wyniki w zakresie ogólnej jakości życia i zdrowia, a także w dziedzinach psychologicznej i środowiskowej w porównaniu z kobietami $(p<0,05)$. U pacjentów będących w związkach małżeńskich stwierdzono wyższą globalną jakość życia i własnego zdrowia oraz w dziedzinach fizycznej, psychologicznej i środowiskowej $(p<0,01)$. Wyższy poziom wykształcenia wiązał się z lepszą jakością życia i zdrowia, a także z lepszą oceną we wszystkich dziedzinach funkcjonowania $(p<0,05)$. Osoby aktywne zawodowo miały wyższą jakość życia i zdrowia w porównaniu z osobami będącymi na emeryturze $(p<0,001)$.

Wnioski: Na jakość życia pacjentów po zawale serca miały wpływ czynniki socjodemograficzne, takie jak wiek, płeć, stan cywilny, wykształcenie oraz status zawodowy. 


\section{Introduction}

Cardiovascular diseases, especially coronary heart disease, are responsible for the highest number of deaths in Poland and worldwide. According to data of the World Health Organization (WHO), the projected mortality from cardiac diseases in 2020 will amount to 20 million people per year, including about $11 \mathrm{mil}$ lion due to ischemic heart disease, and this will be the main cause of death [1].

Acute coronary syndrome is a clinical syndrome caused by discontinuation of blood flow or increasing restriction of blood flow through the coronary artery, leading to myocardial necrosis in some patients. The most common cause is a thrombus at the site of atherosclerotic plaque rupture. This is a life-threatening condition and requires the quickest possible hospitalization, invasive treatment, which is an opportunity for the patient to lead a normal life after myocardial infarction [2].

Research in recent years has shown that the absence of disease is not a determinant of health. According to the World Health Organization (WHO), quality of life is "an individual's perception of their position in the cultural context and value system in which they live and in relation to the goals, expectations and standards set by environmental conditions". Indicators of quality of life include the ability to perform existing social and life roles, adaptability, psychological well-being and functioning within social groups [3].

The development of medicine, including invasive cardiology, allowed the vast majority of patients to survive myocardial infarction. Not always patients can return to work and continue to live as they did before the disease. This has a significant impact on their lives.

A critical event associated with the onset of sudden illness has a significant impact on the quality of life of the patient. Under the conditions of illness, there is a loss of vitality, insecurity, anxiety and loss of meaning in life. Over time, the patient gets used to the new situation. The patient acquires new skills to cope with the symptoms of the disease, realistically assesses his options. This makes assessment of your life situation and the quality of life more realistic than at the beginning of the disease [4]. Currently, medicine knows how to save a patient with acute myocardial infarction. There have been many studies of various quality of life variables in patients with myocardial infarction (MI) from different countries. The research of Arnold et al. shows that older age and being a man are associated with a higher quality of life [5], while another study found that younger age and female sex were associated with a better quality of life [6]. It can be helpful to identify factors affecting the quality of life, to detect patients who may have worse quality of life at various times after a heart attack. Based on quality of life determinants, developing strategies that reduce the impact of a heart attack on patient's experience and health may be necessary in post-heart care [7].

Nowadays, medicine knows how to save a patient with an acute MI, the study states what demographic factors affect the quality of life of patients after myocardial infarction.

\section{Aim of the research}

The aim of the study was to assess the relationship between demographic factors and quality of life of patients after myocardial infarction.

\section{Material and methods}

The study was conducted in the St. Luke Provincial Hospital in Tarnów at the Department of Cardiology and in the Cardiology Outpatient Clinic in the period from September to December 2017. The examined group comprised patients after ST-elevation myocardial infarction (STEMI) and non-ST-elevation myocardial infarction (NSTEMI) myocardial infarction. The criteria for inclusion in the study were the patient's informed consent and the condition after myocardial infarction. Exclusion criteria were the lack of patient's consent and the patient being unable to complete the survey. The Director of the St. Luke Hospital in Tarnów gave the permission to conduct the study. The examination was carried out using a diagnostic survey method. An interview questionnaire was used, which contained 21 closed and open questions. The questionnaire contained questions concerning sociodemographic data.

The study also used a shortened version of the WHOQOL-BREF (World Health Organization Quality of Life Questionnaires) in the Polish adaptation developed by Wołowicka and Jaracz from the Poznan University of Medical Sciences. The questionnaire consists of 26 questions and is a tool designed to assess the quality of life of healthy and ill people [8]. The questions concern general life satisfaction and health, then cover four areas of life: physical, psychological, social and environmental. The patient answers questions about their feelings in this area of life in the last two weeks. The scoring scale ranges from 1 to 5 , where the higher the value, the more positive its overtones (in the context of quality of life). Items scored 1-5. Raw domain score is the sum of respective item scores. All domain scores are reported between 4 and 20 (mean scores for each multiplied by 4 ) [9-11].

\section{Statistical analysis}

The analysis of quantitative variables (i.e., expressed in numbers) was carried out by calculating the mean, standard deviation, median, quartile, minimum and maximum. The analysis of qualitative variables (i.e., not expressed in numbers) was performed by calculating the number and percentage of each val- 
Table 1. Characteristics of patients after myocardial infarction

\begin{tabular}{|c|c|c|c|}
\hline Variables & & $N$ & $\%$ \\
\hline \multirow[t]{2}{*}{ Sex } & Women & 24 & 24.00 \\
\hline & Men & 76 & 76.00 \\
\hline \multirow{4}{*}{$\begin{array}{l}\text { Marital } \\
\text { status }\end{array}$} & Single & 1 & 1.00 \\
\hline & Married & 73 & 73.00 \\
\hline & Widowed & 22 & 22.00 \\
\hline & Divorced & 4 & 4.00 \\
\hline \multirow{2}{*}{$\begin{array}{l}\text { Place of } \\
\text { residence }\end{array}$} & City & 34 & 34.00 \\
\hline & Village & 66 & 66.00 \\
\hline \multirow[t]{4}{*}{ Education } & Primary & 15 & 15.00 \\
\hline & Vocational & 50 & 50.00 \\
\hline & Secondary & 28 & 28.00 \\
\hline & Higher & 7 & 7.00 \\
\hline \multirow{5}{*}{$\begin{array}{l}\text { Family } \\
\text { status }\end{array}$} & Lives alone & 3 & 3.00 \\
\hline & $\begin{array}{l}\text { Lives with wife/ } \\
\text { husband }\end{array}$ & 73 & 73.00 \\
\hline & $\begin{array}{l}\text { Lives with } \\
\text { a partner }\end{array}$ & 2 & 2.00 \\
\hline & Lives with children & 35 & 35.00 \\
\hline & Lives with parents & 6 & 6.00 \\
\hline \multirow{4}{*}{$\begin{array}{l}\text { Professional } \\
\text { status }\end{array}$} & Manual worker & 31 & 31.00 \\
\hline & Office worker & 9 & 9.00 \\
\hline & $\begin{array}{l}\text { On pension/ } \\
\text { retired }\end{array}$ & 60 & 60.00 \\
\hline & $\begin{array}{l}\text { Without } \\
\text { employment }\end{array}$ & 0 & 0.00 \\
\hline \multirow[t]{2}{*}{$\begin{array}{l}\text { Myocardial } \\
\text { infarction }\end{array}$} & $\begin{array}{l}\text { Subsequent } \\
\text { infarction }\end{array}$ & 25 & 25.00 \\
\hline & First infarction & 75 & 75.00 \\
\hline \multirow{4}{*}{$\begin{array}{l}\text { Time from } \\
\text { the last } \\
\text { myocardial } \\
\text { infarction }\end{array}$} & 6-12 months & 55 & 55.00 \\
\hline & 2 years & 38 & 38.00 \\
\hline & 3 years & 7 & 7.00 \\
\hline & 4 years and more & 0 & 0.00 \\
\hline \multirow{2}{*}{$\begin{array}{l}\text { Treatment } \\
\text { applied }\end{array}$} & Invasive (PCI) & 91 & 91.00 \\
\hline & $\begin{array}{c}\text { Conservative } \\
\text { (pharmacological) }\end{array}$ & 9 & 9.00 \\
\hline
\end{tabular}

$N$-number of patients.

ue occurrences. Normality of variables distribution was studied using the Shapiro-Wilk test. Since the analyzed quantitative variables did not have normal distribution: the comparison in two groups was made with the Mann-Whitney test; the comparison in three or more groups was made with the Kruskal-Wallis test. If it showed statistically significant differences, a post-hoc analysis (Dunn's test) was performed to determine which exactly groups differ from each other.

In the analysis, the significance level of 0.05 was assumed. Thus, all $p$-values below 0.05 were interpreted as indicating significant relationships. The analysis was performed using R software, version 3.4.3.

\section{Results}

The average age of the subjects was $66.76 \pm 10.04$ years and ranged from 40 to 89 years. The median was 67.5 years, so half of the respondents were younger and half older than 67.5 years. The first and third quartile were 61 and 74 years, respectively, so the typical age in the study group was between 61 and 74 years.

Men were a much larger group than women (76.00\% vs. $24.00 \%)$, in most cases married (73.00\%), living in the countryside $(66.00 \%)$, with vocational education $(50.00 \%)$. Most of the respondents lived with their spouses $(73.00 \%)$, and at the time of the study they were pensioners or retired (60.00\%).

For $75 \%$ of the respondents it was the first myocardial infarction in their lives, in most cases $(91.00 \%)$ invasive treatment was used. For more than half of the patients (55.00\%), between 6 and 12 months passed since the last myocardial infarction. Detailed data concerning the characteristics of the examined patients are presented in Table 1.

The average quality of life assessment made by the respondents was $3.52 \pm 0.86$ points, which means that they assessed their quality of life between good and average (neither good nor bad).

The respondents' average assessment of their health status was $3.44 \pm 0.92$ points, which means that they assessed their health between satisfactory and average (neither satisfactory nor unsatisfactory).

The respondents had the best opinion of their quality of life in the physical field, a slightly worse quality of life in the social field and the worst quality of life in the psychological and environmental field.

\section{Age}

Age had no normal distribution ( $p$ from the Shapiro-Wilk test below 0.05), so the Spearman correlation coefficient was used in the analysis.

Age had a significant impact on the quality of life in each area (all $p$ are lower than 0.05). These correlations are negative, i.e., the older the age, the lower the quality of life. Age has the strongest impact on the physical and psychological quality of life (Table 2).

\section{Gender}

WHOQOL-BREF results did not have a normal distribution in the analyzed groups ( $p$ of ShapiroWilk test below 0.05).

The $p$-values were lower than 0.05 for the perception of quality of life and own health and for the qual- 
Table 2. Correlation of the WHOQOL-BREF scale with the age of patients after myocardial infarction

\begin{tabular}{|lcccc|}
\hline WHOQOL-BREF & \multicolumn{3}{c|}{ Correlation with age } \\
\cline { 2 - 5 } & $\begin{array}{c}\text { Correlation } \\
\text { coefficient }\end{array}$ & P-value & $\begin{array}{c}\text { Direction } \\
\text { of dependence }\end{array}$ & $\begin{array}{c}\text { Power } \\
\text { of dependence }\end{array}$ \\
Perception of quality of life & -0.69 & $<0.001$ & Negative & Moderate \\
Perception of own health & -0.68 & $<0.001$ & Negative & Moderate \\
Physical area & -0.771 & $<0.001$ & Negative & Strong \\
Psychological area & -0.705 & $<0.001$ & Negative & Strong \\
Social area & -0.321 & 0.001 & Negative & Weak \\
Environmental area & -0.592 & $<0.001$ & Negative & Moderate \\
\hline
\end{tabular}

$p$-significance level.

ity of life in psychological and environmental areas, so the quality of life in these areas was sex-dependent. It was higher in men (Table 3).

\section{Marital status}

WHOQOL-BREF results did not have normal distribution in the analyzed groups ( $p$ of Shapiro-Wilk test below 0.05 ). Only one person was single and 4 were divorced. They were joined to widowed people, forming the group "Others".

The $p$-values are lower than 0.05 for the perception of quality of life and own health and for the quality of life in physical, psychological and environmental areas, so the quality of life in these areas depended on marital status. In married patients it was higher than in other patients (Table 4).

\section{Place of residence}

WHOQOL-BREF results did not have a normal distribution in the analyzed groups ( $p$ of ShapiroWilk test below 0.05).

All $p$-values were higher than 0.05 , so the quality of life in none of the areas depended on residence.

\section{Education}

The WHOQOL-BREF results did not show normal distribution in the analyzed groups ( $p$ of ShapiroWilk test below 0.05). Only 7 people had higher education. They were joined to people with secondary education.

All $p$-values were below 0.05 , so the quality of life in each area depended on education. To answer the question how exactly this dependence looked like,

Table 3. Quality of life of patients after myocardial infarction according to WHOQOL-BREF and sex

\begin{tabular}{|c|c|c|c|c|c|c|c|c|c|c|}
\hline WHOQOL-BREF & Sex & $N$ & Mean & SD & Median & Min. & Max. & Q1 & Q3 & $P$-value* \\
\hline \multirow[t]{2}{*}{ Perception of quality of life } & Women & 24 & 3.12 & 1.03 & 3 & 2 & 5 & 2 & 3.25 & 0.007 \\
\hline & Men & 76 & 3.64 & 0.76 & 4 & 2 & 5 & 3 & 4 & \\
\hline \multirow[t]{2}{*}{ Perception of own health } & Women & 24 & 3.08 & 1.1 & 3 & 1 & 5 & 2 & 3.25 & 0.025 \\
\hline & Men & 76 & 3.55 & 0.84 & 4 & 2 & 5 & 3 & 4 & \\
\hline \multirow[t]{2}{*}{ Physical area } & Women & 24 & 12.62 & 2.63 & 12.5 & 8 & 17 & 10.75 & 14.25 & 0.111 \\
\hline & Men & 76 & 13.45 & 2.25 & 14 & 7 & 18 & 13 & 15 & \\
\hline \multirow[t]{2}{*}{ Psychological area } & Women & 24 & 12.33 & 2.18 & 11 & 9 & 18 & 11 & 13.25 & 0.033 \\
\hline & Men & 76 & 13.2 & 2.07 & 13 & 7 & 19 & 11.75 & 14.25 & \\
\hline \multirow[t]{2}{*}{ Social area } & Women & 24 & 13.29 & 2.4 & 13 & 9 & 16 & 12 & 16 & 0.841 \\
\hline & Men & 76 & 13.17 & 2.66 & 13 & 7 & 19 & 11 & 15.25 & \\
\hline \multirow[t]{2}{*}{ Environmental area } & Women & 24 & 11.04 & 1.99 & 10 & 9 & 16 & 10 & 11.25 & $<0.001$ \\
\hline & Men & 76 & 12.78 & 1.69 & 13 & 9 & 16 & 12 & 14 & \\
\hline
\end{tabular}

$N$ - number of patients, SD - standard deviation, min. - minimum, max. - maximum, Q1 - quartile 1, Q3 - quartile 3, $p$ - significance level, *Mann-Whitney test. 
Table 4. Quality of life of patients after myocardial infarction according to WHOQOL-BREF and marital status

\begin{tabular}{|c|c|c|c|c|c|c|c|c|c|c|}
\hline WHOQOL-BREF & Marital status & $N$ & Mean & SD & Median & Min. & Max. & Q1 & Q3 & $P$-value* \\
\hline \multirow{2}{*}{$\begin{array}{l}\text { Perception of quality } \\
\text { of life }\end{array}$} & Married & 73 & 3.7 & 0.79 & 4 & 2 & 5 & 3 & 4 & $<0.001$ \\
\hline & Others & 27 & 3.04 & 0.85 & 3 & 2 & 5 & 2.5 & 3 & \\
\hline \multirow{2}{*}{$\begin{array}{l}\text { Perception of own } \\
\text { health }\end{array}$} & Married & 73 & 3.6 & 0.91 & 4 & 1 & 5 & 3 & 4 & 0.002 \\
\hline & Others & 27 & 3 & 0.83 & 3 & 2 & 5 & 2.5 & 3 & \\
\hline \multirow[t]{2}{*}{ Physical area } & Married & 73 & 13.7 & 2.15 & 14 & 7 & 18 & 13 & 15 & 0.002 \\
\hline & Others & 27 & 12.04 & 2.52 & 12 & 7 & 17 & 10.5 & 14 & \\
\hline \multirow[t]{2}{*}{ Psychological area } & Married & 73 & 13.44 & 1.98 & 13 & 7 & 18 & 12 & 15 & $<0.001$ \\
\hline & Others & 27 & 11.78 & 2.04 & 11 & 9 & 19 & 11 & 12.5 & \\
\hline \multirow[t]{2}{*}{ Social area } & Married & 73 & 13.41 & 2.45 & 13 & 7 & 17 & 12 & 16 & 0.167 \\
\hline & Others & 27 & 12.63 & 2.91 & 12 & 8 & 19 & 11 & 15 & \\
\hline \multirow[t]{2}{*}{ Environmental area } & Married & 73 & 13 & 1.67 & 13 & 9 & 16 & 12 & 14 & $<0.001$ \\
\hline & Others & 27 & 10.63 & 1.36 & 10 & 9 & 16 & 10 & 11 & \\
\hline
\end{tabular}

$N$ - number of patients, SD - standard deviation, min. - minimum, max. - maximum, Q1 - quartile 1, Q3-quartile 3, $p$ - significance level, *Mann-Whitney test.

a post-hoc analysis was performed. It showed that perception of quality of life was higher if the education was higher. The details are presented in Table 5.

\section{Family status}

WHOQOL-BREF results did not have a normal distribution in the analyzed groups ( $p$ of ShapiroWilk test below 0.05).

All $p$-values were below 0.05 , so the quality of life in each area depended on living with a spouse/partner. In patients living with their spouse/partner it was higher (Table 6).

\section{Professional status}

WHOQOL-BREF results did not have normal distribution in the analyzed groups ( $p$ of Shapiro-Wilk test below 0.05). Only 9 people did intellectual work. They were joined to people involved in manual work.

All $p$-values were below 0.05 , so the quality of life in each area depended on professional status. In working patients it was higher than in pensioners and retired respondents (Table 7 ).

\section{Discussion}

Due to their high prevalence, cardiovascular diseases are the dominant health and social problem in Poland. Every year, 100 thousand people in our country suffer from myocardial infarction and the mortality rate is still high.

Quality of life is a subjective sense of satisfaction experienced by a person and influences the physical, mental, social, and religious areas of life, therefore it is an important element in the assessment of patients' health [12]. It should be emphasized that the quality of life assessment in people with various cardiovascular diseases is as important as the results of physical, laboratory and clinical studies, and such examinations can be used to assess the effectiveness of the treatment and therapeutic process.

Our study showed that the respondents assessed their quality of life between good and average. In turn, the quality of their health was assessed between satisfactory and average. The quality of life of cardiac patients is also of interest to other authors. Similar results were obtained by Orłowski and Humańska who using the WHOQOL-BREF scale examined patients after myocardial infarction in the Cardiology Clinic of the $10^{\text {th }}$ Military Clinical Hospital with Polyclinic in Bydgoszcz. They demonstrated that the vast majority of patients treated for myocardial infarction were satisfied with the quality of their lives (73.3\%), and almost half of them were dissatisfied with their condition [13].

According to the literature on the subject, the quality of life in various disease units, including cardiovascular diseases, may be associated with various sociodemographic factors. The analysis of our study showed a statistically significant relationship between the overall quality of life and own health in psychological and environmental areas and the sex of the subjects (it was higher in men). Similar results were obtained by Munyombwe et al. who, having examined 9566 patients after myocardial infarction in England, demonstrated that women declared worse quality of life [14]. The study conducted by Huffman et al. in patients 30 days after myocardial infarction did not demonstrate the relationship between sex and overall quality of life [15]. Similarly, the study by Kurpas et al. 
Table 5. Quality of life of patients after myocardial infarction according to WHOQOL-BREF and education

\begin{tabular}{|c|c|c|c|c|c|c|c|c|c|c|}
\hline WHOQOL-BREF & Education & $N$ & Mean & SD & Median & Min. & Max. & Q1 & Q3 & $P$-value* \\
\hline \multirow{3}{*}{$\begin{array}{l}\text { Perception of } \\
\text { quality of life }\end{array}$} & Primary & 15 & 2.8 & 0.68 & 3 & 2 & 4 & 2 & 3 & \multirow[t]{3}{*}{$<0.001$} \\
\hline & Vocational & 50 & 3.44 & 0.79 & 3.5 & 2 & & 3 & 4 & \\
\hline & $\begin{array}{c}\text { Secondary, } \\
\text { higher }\end{array}$ & 35 & 3.94 & 0.8 & 4 & 2 & 5 & 4 & 4 & \\
\hline \multirow{3}{*}{$\begin{array}{l}\text { Perception of } \\
\text { own health }\end{array}$} & Primary & 15 & 2.8 & 0.68 & 3 & 2 & 4 & 2 & 3 & \multirow[t]{3}{*}{$<0.001$} \\
\hline & Vocational & 50 & 3.34 & 0.87 & 3 & 1 & 5 & 3 & 4 & \\
\hline & $\begin{array}{c}\text { Secondary, } \\
\text { higher }\end{array}$ & 35 & 3.86 & 0.91 & 4 & 2 & 5 & 3 & 4.5 & \\
\hline \multirow[t]{3}{*}{ Physical area } & Primary & 15 & 10.87 & 1.77 & 11 & 8 & 14 & 9.5 & 12 & \multirow[t]{3}{*}{$<0.001$} \\
\hline & Vocational & 50 & 13.36 & 2.31 & 13 & 7 & 18 & 12.25 & 15 & \\
\hline & $\begin{array}{c}\text { Secondary, } \\
\text { higher }\end{array}$ & 35 & 14.11 & 2 & 14 & 8 & 18 & 14 & 15 & \\
\hline \multirow{3}{*}{$\begin{array}{l}\text { Psychological } \\
\text { area }\end{array}$} & Primary & 15 & 11.27 & 0.96 & 11 & 9 & 13 & 11 & 11.5 & \multirow[t]{3}{*}{$<0.001$} \\
\hline & Vocational & 50 & 12.76 & 1.89 & 13 & 7 & 17 & 11.25 & 13.75 & \\
\hline & $\begin{array}{c}\text { Secondary, } \\
\text { higher }\end{array}$ & 35 & 14.06 & 2.24 & 14 & 11 & 19 & 12.5 & 16 & \\
\hline \multirow[t]{3}{*}{ Social area } & Primary & 15 & 13.13 & 2.07 & 13 & 9 & 16 & 12 & 15 & \multirow[t]{3}{*}{0.017} \\
\hline & Vocational & 50 & 12.5 & 2.63 & 13 & 7 & 17 & 11 & 14.5 & \\
\hline & $\begin{array}{l}\text { Secondary, } \\
\text { higher }\end{array}$ & 35 & 14.23 & 2.45 & 15 & 9 & 19 & 13 & 16 & \\
\hline \multirow{3}{*}{$\begin{array}{l}\text { Environmental } \\
\text { area }\end{array}$} & Primary & 15 & 11.07 & 1.58 & 10 & 9 & 14 & 10 & 12 & \multirow[t]{3}{*}{0.002} \\
\hline & Vocational & 50 & 12.24 & 1.76 & 12 & 9 & 16 & 11 & 14 & \\
\hline & $\begin{array}{c}\text { Secondary, } \\
\text { higher }\end{array}$ & 35 & 13.09 & 1.96 & 14 & 10 & 16 & 12 & 14 & \\
\hline
\end{tabular}

$N$ - number of patients, SD - standard deviation, min. - minimum, max. - maximum, Q1 - quartile 1, Q3 - quartile 3, $p$ - significance level; *Kruskal-Wallis test + post-hoc analysis (Dunn's test).

Table 6. Quality of life of patients after myocardial infarction according to WHOQOL-BREF and living with a partner

\begin{tabular}{|c|c|c|c|c|c|c|c|c|c|c|}
\hline WHOQOL-BREF & $\begin{array}{l}\text { Living with a spouse/ } \\
\text { partner }\end{array}$ & $N$ & Mean & SD & Median & Min. & Max. & Q1 & Q3 & $P$-value* \\
\hline \multirow{2}{*}{$\begin{array}{l}\text { Perception of } \\
\text { quality of life }\end{array}$} & No & 25 & 2.96 & 0.79 & 3 & 2 & 5 & 2 & 3 & $<0.001$ \\
\hline & Yes & 75 & 3.71 & 0.8 & 4 & 2 & 5 & 3 & 4 & \\
\hline \multirow{2}{*}{$\begin{array}{l}\text { Perception of } \\
\text { own health }\end{array}$} & No & 25 & 2.92 & 0.76 & 3 & 2 & 5 & 2 & 3 & 0.001 \\
\hline & Yes & 75 & 3.61 & 0.91 & 4 & 1 & 5 & 3 & 4 & \\
\hline \multirow[t]{2}{*}{ Physical area } & No & 25 & 11.96 & 2.54 & 12 & 7 & 17 & 10 & 14 & 0.002 \\
\hline & Yes & 75 & 13.68 & 2.15 & 14 & 7 & 18 & 13 & 15 & \\
\hline \multirow{2}{*}{$\begin{array}{l}\text { Psychological } \\
\text { area }\end{array}$} & No & 25 & 11.52 & 1.5 & 11 & 9 & 16 & 11 & 12 & $<0.001$ \\
\hline & Yes & 75 & 13.48 & 2.08 & 13 & 7 & 19 & 12 & 15 & \\
\hline \multirow[t]{2}{*}{ Social area } & No & 25 & 12.24 & 2.62 & 12 & 8 & 16 & 11 & 15 & 0.037 \\
\hline & Yes & 75 & 13.52 & 2.52 & 13 & 7 & 19 & 12 & 16 & \\
\hline \multirow{2}{*}{$\begin{array}{l}\text { Environmental } \\
\text { area }\end{array}$} & No & 25 & 10.44 & 0.87 & 10 & 9 & 12 & 10 & 11 & $<0.001$ \\
\hline & Yes & 75 & 13 & 1.72 & 13 & 9 & 16 & 12 & 14 & \\
\hline
\end{tabular}

$N$ - number of patients, SD - standard deviation, min. - minimum, max. - maximum, Q1 - quartile 1, Q3 - quartile 3, $p$ - significance level, *Mann-Whitney test. 
Table 7. Quality of life of patients after myocardial infarction according to WHOQOL-BREF and professional status

\begin{tabular}{|c|c|c|c|c|c|c|c|c|c|c|}
\hline WHOQOL-BREF & Professional status & $N$ & Mean & SD & Median & Min. & Max. & Q1 & Q3 & $P$-value* \\
\hline \multirow{2}{*}{$\begin{array}{l}\text { Perception of } \\
\text { quality of life }\end{array}$} & Employed & 40 & 4.05 & 0.68 & 4 & 2 & 5 & 4 & 4 & $<0.001$ \\
\hline & On pension/retired & 60 & 3.17 & 0.78 & 3 & 2 & 5 & 3 & 4 & \\
\hline \multirow{2}{*}{$\begin{array}{l}\text { Perception of } \\
\text { own health }\end{array}$} & Employed & 40 & 4.03 & 0.73 & 4 & 2 & 5 & 4 & 4.25 & $<0.001$ \\
\hline & On pension/retired & 60 & 3.05 & 0.83 & 3 & 1 & 5 & 3 & 3.25 & \\
\hline \multirow[t]{2}{*}{ Physical area } & Employed & 40 & 14.88 & 1.47 & 15 & 11 & 18 & 14 & 16 & $<0.001$ \\
\hline & On pension/retired & 60 & 12.17 & 2.23 & 13 & 7 & 18 & 11 & 14 & \\
\hline \multirow{2}{*}{$\begin{array}{l}\text { Psychological } \\
\text { area }\end{array}$} & Employed & 40 & 14.35 & 1.98 & 14 & 11 & 19 & 13 & 16 & $<0.001$ \\
\hline & On pension/retired & 60 & 12.08 & 1.69 & 12 & 7 & 16 & 11 & 13 & \\
\hline \multirow[t]{2}{*}{ Social area } & Employed & 40 & 14.35 & 2.54 & 15 & 8 & 19 & 13 & 16 & $<0.001$ \\
\hline & On pension/retired & 60 & 12.43 & 2.35 & 12 & 7 & 17 & 11 & 13 & \\
\hline \multirow{2}{*}{$\begin{array}{l}\text { Environmental } \\
\text { area }\end{array}$} & Employed & 40 & 13.32 & 1.7 & 14 & 10 & 16 & 12 & 14 & $<0.001$ \\
\hline & On pension/retired & 60 & 11.72 & 1.78 & 12 & 9 & 16 & 10 & 13 & \\
\hline
\end{tabular}

$N$ - number of patients, SD - standard deviation, min. - minimum, max. - maximum, Q1-quartile 1, Q3-quartile 3, $p$ - significance level, *Mann-Whitney test.

who evaluated the quality of life of patients of the Invasive Cardiology Department did not show any relation between sex and overall quality of life [16].

Another sociodemographic factor that affects the quality of life of people after myocardial infarction is their marital status. This relationship was demonstrated by Kurpas et al. - married patients evaluated the quality of life much higher in the social area [16]. A similar result was presented by Kurowska and Korecińska when determining the quality of life of patients after cardiac surgeries; they observed the relation between the patients' marital status and the social area of quality of life, here also the highest level was observed in married people [17]. The results of the above-mentioned studies correlate with our results as the quality of life and health in married patients (and those living with their spouse/partner) was significantly higher than in the remaining respondents. Very often, spouses play the role of a caregiver for people after myocardial infarction. The correct relation of the caregiver-patient strengthens the patient's sense of security, and relieves depression, anxiety, and loneliness [18].

Our analysis shows that the quality of life is also significantly influenced by age, i.e., the older the patient, the lower both the overall quality of life and health and the quality of life in each area. Similar results were obtained by Uchmanowicz et al. [19], who showed that the age $>65$ years had a negative effect on the quality of life in the group of patients after coronary angioplasty. The study by Błaszczyk et al. [12] also showed that younger patients after myocardial infarction had a higher quality of life than older ones. Juzwiszyn et al. [20] demonstrated that in patients with ischemic heart disease, the older age $>60$ years had a worsening effect on the quality of life in the psychological and independent areas, both before and after PCI. Also a study by Huffman et al. showed that as the age of the subjects increased, limitations on physical fitness increased, but satisfaction with treatment results and quality of life evaluation decreased [15].

Similarly to the study by Szyguła-Jurkiewicz et al. [21] on the quality of life of patients with cardiovascular diseases, the analysis of our study shows the relation between the quality of life and education - the higher the education the better the quality of life in the psychological, physical, social and environmental areas. Also the study conducted by Błaszczyk et al. [12] shows that an increase in the education level results in an increase in the quality of life of patients. Also the study by Kang et al. conducted in South Korean patients using the HRQoL questionnaire showed that a lower quality of life was associated with a lower level of education and a lower financial status [22], while the study by Huo et al. conducted in the Chinese group of patients hospitalized for myocardial infarction confirmed the association between a low level of education and a higher risk of adverse events in the year following discharge [23]. Different results were obtained by Płaczak and Uchmanowicz [24], who stated that the education of patients after myocardial infarction did not significantly affect the quality of life results.

The financial status is related to the possibility of taking up employment after myocardial infarction. The inability to work after acute myocardial infarction (MI) has important implications for the patients. Our study showed that the quality of life in working patients was higher than in retired patients or pensioners. Similar results were obtained by Warraich et al. TRANSLATE-ACS study demonstrated that pa- 
tients who experienced an adverse change in employment after myocardial infarction reported a lower quality of life, increased depression and greater difficulty in administering drugs [25].

Myocardial infarction is a serious problem for many patients, but despite the associated risks, the patient can lead a normal life and the infarction incident itself usually does not limit the patient's future possibilities.

The relationships between mental, somatic, emotional and social functioning of patients and the severity of cardiovascular ailments make the assessment of quality of life more important. The study of subjective assessment of patients' health is an important cognitive, practical and prognostic factor, which may significantly affect the comprehensive assessment of the effectiveness of the applied treatment, the choice of management strategy, or the definition of patients' expectations. This, in turn, allows to recognize the areas which cause most problems to the patient and result from their health condition. Moreover, it can also provide valuable guidance in planning individual patient care and their caregiver [18]. They emphasize the need to consider interventions to improve the quality of life after myocardial infarction in adults with low levels of education and those without employment.

\section{Conclusions}

Patients after myocardial infarction evaluated their quality of life between good and average, while their quality of health between satisfactory and average. Sociodemographic factors such as age, sex, marital status, education and professional status had an impact on the quality of life of patients after myocardial infarction. Subjective assessment of patients' health is an important cognitive, practical and prognostic factor which can significantly influence the comprehensive assessment of the effectiveness of the applied treatment, the choice of management strategy or the definition of patients' expectations.

\section{Conflict of interest}

The authors declare no conflict of interest.

\section{References}

1. Cieślik B. Wpływ chorób serca na jakość życia - opracowanie na podstawie przeglądu piśmiennictwa. Acta Bio-Optica Inżynieria Biomedyczna 2014; 20: 101-118.

2. Szczeklik A, Budaj A. Choroby wewnętrzne. In: Interna Szczeklika. Podręcznik chorób wewnętrznych 2016. Medycyna Praktyczna, Kraków 2016; 168-223.

3. Woynarowska B. Edukacja zdrowotna. Wydawnictwo Naukowe PZWL, Warszawa 2013; 41-42.

4. Rolka H, Jankowiak B. Jakość życia pacjentów w stanie zagrożenia życia hospitalizowanych na oddziałach intensywnej terapii medycznej. In: Standardy i procedury pielęgnowania chorych w stanach zagrożenia życia. Kra-
jewska-Kułak E, Rolka H (eds). Wydawnictwo Lekarskie PZWL, Warszawa 2009; 28-32.

5. Arnold SV, Masoudi FA, Rumsfeld JS, Li Y, Jones PG, Spertus JA. Derivation and validation of a risk standardization model for benchmarking hospital performance for health-related quality of life outcomes after acute myocardial infarction. Circulation 2013; 129: 313-320.

6. Oginska-Bulik N. Type D personality and quality of life in subjects after myocardial infarction. Pol Heart J 2014; 72: 624-630.

7. Hawkes AL, Patrao TA, Ware R, Atherton JJ, Taylor CB, Oldenburg BF. Predictors of physical and mental health-related quality of life outcomes among myocardial infarction patients. BMC Cardiovasc Disord 2013; 13: 69.

8. Jaracz K. WOQOL BREF Klucz. In: Jakość życia w naukach medycznych. Wołowicka L (ed.). Dział Wydawnictw Uczelnianych AM 2001; 259-280.

9. Cieślik B, Podbielska H. Przegląd wybranych kwestionariuszy oceny jakości życia. Medycyna spersonalizowana Acta Bio-Optica et Informatica Medica Inżynieria Biomedyczna 2015; 21: 102-135.

10. Kłak A, Mińko M, Siwczyńska D. Metody kwestionariuszowe badania jakości życia. Probl Hig Epidemiol 2012; 93: 632-638.

11. Gnacińska-Szymańska M, Dardzińska JA, Majkowicz M, Małgorzewicz S. Ocena jakości życia osób z nadmierną masą ciała za pomocą formularza WHOQOL-BREF. Endokrynol Otył Zab Przem Mat 2012; 8: 136-142.

12. Błaszczyk I, Uchmanowicz I, Jankowska-Polańska B, Lisiak M, Obiegło M. Jakość życia pacjentów po zawale mięśnia sercowego. Współcz Pieleg Ochrona Zdrowia 2012; 1: 76-80.

13. Orłowski P, Humańska M. Jakość życia pacjentów po zawale mięśnia sercowego. Pieleg Opiece Długoterminowej 2017; 2: 29-44.

14. Munyombwe T, Hall M, Dondo TB, Alabas OA, Gerard O, West RM, Pujades-Rodriguez M, Hall A, Gale CP. Quality of life trajectories in survivors of acute myocardial infarction: a national longitudinal study. Heart 2020; 106: 33-39.

15. Huffman MD, Mohanan PP, Devarajan R, Baldridge AS, Kondal D, Zhao L, Ali M, Spertus J, Chan PS, Natesan S, Abdullakutty J, Krishnan MN, Tp A, Renga S, Punnoose E, Unni G, Prabhakaran D, Lloyd-Jones DM; ACS QUIK Investigators. Health-related quality of life at 30 days among indian patients with acute myocardial infarction. Circ Cardiovasc Qual Outcomes 2019; 12 e004980.

16. Kurpas D, Bąk E, Seń M, Wróblewska I, Mroczek B. Jakość życia pacjentów oddziału kardiologii inwazyjnej. Fam Med Prim Care Rev 2014; 16: 120-123.

17. Kurowska K, Korecińska M. Wpływ zachowań zdrowotnych na jakość życia chorych po zabiegach kardiochirurgicznych. Piel Chir Angiol 2012; 1: 20-25.

18. Białek K, Sadowski M. Caregivers' burden and other selected problems of patients treated for heart failure. Medical Studies 2019; 35: 82-88.

19. Uchmanowicz I, Łoboz-Grudzień K, Sokalski L. Czynniki wpływające na jakość życia po zabiegu angioplastyki tętnic wieńcowych u chorych ze stabilną chorobą wieńcową. In: Jakość życia w chorobach wewnętrznych. Łoboz-Grudzień K, Uchmanowicz I (eds). Akademia Medyczna, Wrocław 2008; 38-49. 
20. Juzwiszyn J, Mazurek W, Wojewoda B, Janczak D, Grzebieniak T. Wybrane aspekty jakości życia chorych na niedokrwienną chorobę serca poddanych planowej przezskórnej plastyce naczyń wieńcowych. Piel Zdr Publ 2012; 2, 7-13.

21. Szyguła-Jurkiewicz B, Kowalska M, Mościński M. Jakość życia jako element oceny stanu zdrowia i efektywności leczenia chorych ze schorzeniami układu sercowo-naczyniowego. Folia Card Eksperta 2011; 6: 62-71.

22. Kang K, Gholizadeh L, Han HR. Health-related quality of life and its predictors in Korean patients with myocardial infarction in the acute phase. Clin Nursing Res 2019. https://doi.org/10.1177/1054773819894692

23. Huo $X$, Khera R, Zhang L, Herrin J, Bai X, Wang Q, Lu Y, Nasir K, Hu S, Li J, Li X, Zheng X, Masoudi FA, Spertus JA, Krumholz HM, Jiang L. Education level and outcomes after acute myocardial infarction in China. Heart 2019; 105: 946-952.

24. Płaczak E, Uchmanowicz I. Analiza czynników wpływających na jakość życia po zawale mięśnia sercowego. Piel Zdr Publ 2012; 2: 29-37.

25. Warraich HJ, Kaltenbach LA, Fonarow GC, Peterson ED, Wang TY. Adverse change in employment status after acute myocardial infarction: analysis from the TRANSLATE-ACS study. Circ Cardiovasc Qual Outcomes 2018; 11: $\mathrm{e} 004528$.

\section{Address for correspondence:}

Dr. Aneta Grochowska

Department of Nursing

Faculty of Health Sciences

University of Applied Sciences

ul. Mickiewicza 8, 33-100 Tarnów, Poland

E-mail: apea1@op.pl 